\title{
МОНГОЛ ХОНИНЫ НООСНЫ БУТЭЦ, ШИНЖ ЧАНАРЫГ ЭЛЕКТРОН МИКРОСКОПИЙН АРГААР СУДЛАХ
}

\author{
Г.Ганбат ${ }^{1}$, Ц.Хишигжаргал ${ }^{1}$, Ч.Ганзориг ${ }^{2}$, Э.Оюунсүрэн ${ }^{1}$, Л.Ганчимэг ${ }^{2}$ \\ 1-ХААИС, Биологийн нөөцийн менежментийн сургууль \\ 2-МУИС, Хими, хими-инженерчлэлийн сургууль
}

\begin{abstract}
ХУРААНГУЙ
Монгол хониньл ноосны ноолуур, завсрын, сор, ямаан үснүҮдийн хайрслаг давхарга, ияайварлаг давхаргыг электрон микроскопийн аргаар анх удаа судалж тодорхойлсон. Судалгааны үр дүнгээс үзэхэд ноолууран Үсний хайрс нь зөв хэлбэртэй, ширхэгтийн 1мм уртад оногдох хайрсны тоо 58 байхад ямаан үсний хувьд хайрс нь зөв биш хэлбэртэй ширхэгтийн 1мм уртад оногдох хайрсны тоо 67 байна. Цайварлаг давхаргын хувьд авч үзэхэд ноолууран үс нь орто, паракортекс гэсэн 2 хэсгээс тогтдог байна. Хөндлөн огтлольн талбай нь 285,9мкм² байна. Ямаан үсний хувьд хөндлөн огтлольн хувьд ихэнх хувийг нь хөндий гол эзлэн тогтсон байна. Хөндлөн огтлольн талбай нь 10975, 1мкм² байна.
\end{abstract}

ТУЛХУУР ҮГ: Хайрслаг давхарга, цайварлаг давхарга, ортокортекс, паракортекс, хөндий гол

\section{ОРШИЛ}

Ноосон дахь үсний ширхэгтүудийн бүтэц шинж чанарыг нарийвчлан тодорхойлсны үндсэн дээр хялгаслаг ширхэгтээр нэмүү өртөг шингэсэн шинэ төрлийн нэхээсгүй эдлэл бий болгох технологийн шийдлийн зарим үзүүлэлтийг тогтоох зорилго тавьж байна.

Электрон микроскопийн аргаaр ноосны ширхэгтүүдийн бүтцийг анх удаа судалж тодорхойлж байгаа нь судалгааны ажлын шинэлэг тал болно.

\section{СУДАЛГААНЫ ХЭРЭГЛЭГДЭХУУН, АРГА ЗУЙ}

Ширхэгттийн гистологи бүтцийг тодорхойлох судалгаа шинжилгээний дээж, сорьцийг "Нэхээсгүй эдлэл”, “Могол ноос" ХХК-ны бэлтгэсэн хонины ноосноос MNS 2951- 2007 стандартын дагуу бэлтгэн МУИС-ийн дэргэдэх “Наношинжлэх ухаан, Нанотехнологийн төв”-ийн лабораторт ISO17751:2007(E), IWTO DTM-XX-97, ASTM- D2130 шинжилгээний аргачлалын дагуу электрон микроскопон дээр (SEM) судалгааны ажлыг хийж гүйцэтгэсэн. Судалгааны үр дүнг математик статистикийн Data analysis программын Descriptive Statistic Histogram Frequence Polygan дэд программаар боловсруулав.

\section{СУДАЛГААНЫ ҮР ДУН}

Электрон микроскопын аргаар хонины ноосны гистологи бүтэц, шинж чанарын нарийвчилсан судалгааг явууллаа.

1. Гистологи бүтциийн судалгаа

Судалгааны дүнгээс үзэхэд хайрслаг давхаргын хувьд ноолууран үс нь цагираг хэлбэрийн хайрстай, хайрсны өндөр нь дунджаар 15,12мкм, ширхэгтийн 1 мм уртад оногдох хайрсны тоо нь 58 байхад ямаан үс нь цагираг бус хэлбэрийн хайрстай, хайрсны өндөр нь 9,12-24,44мк хооронд хэлбэлзэж, ширхэгтийн 1мм уртад оногдох хайрсны тоо нь 67 байна.

(1, 2-р зураг, 1-р хүснэгт) 


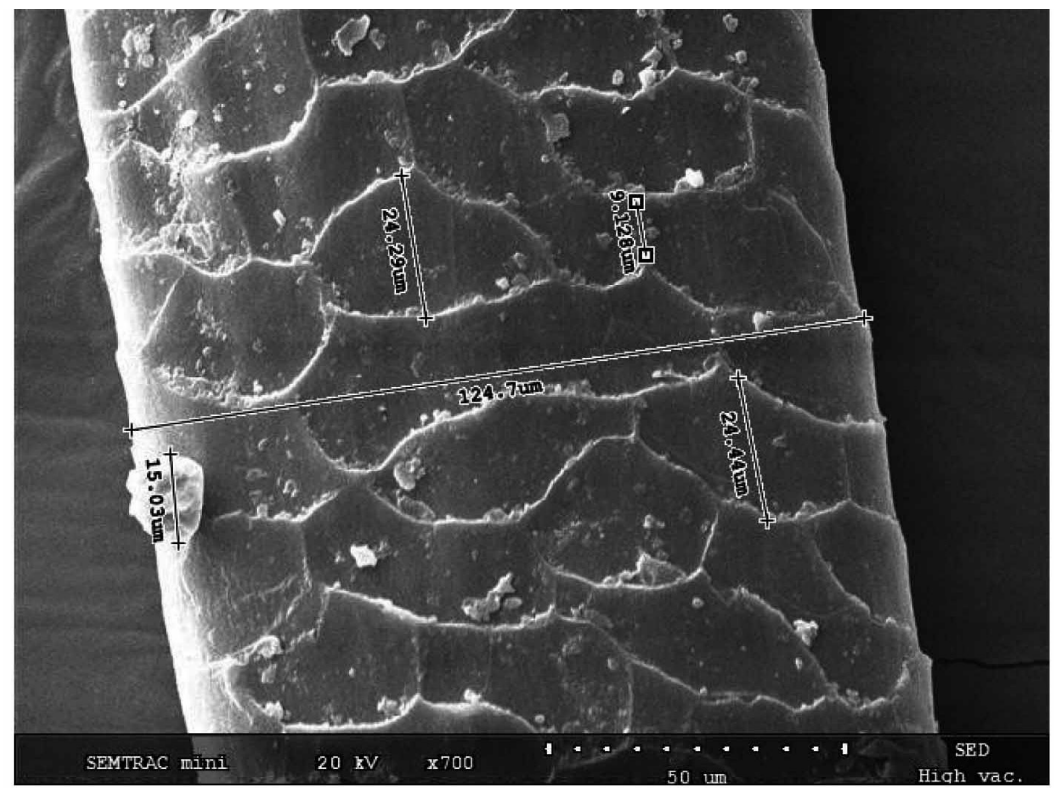

1-р зураг. Ноосны ямаан үсний хайрслаг давхарга (700 дахин өсгөлттэй)

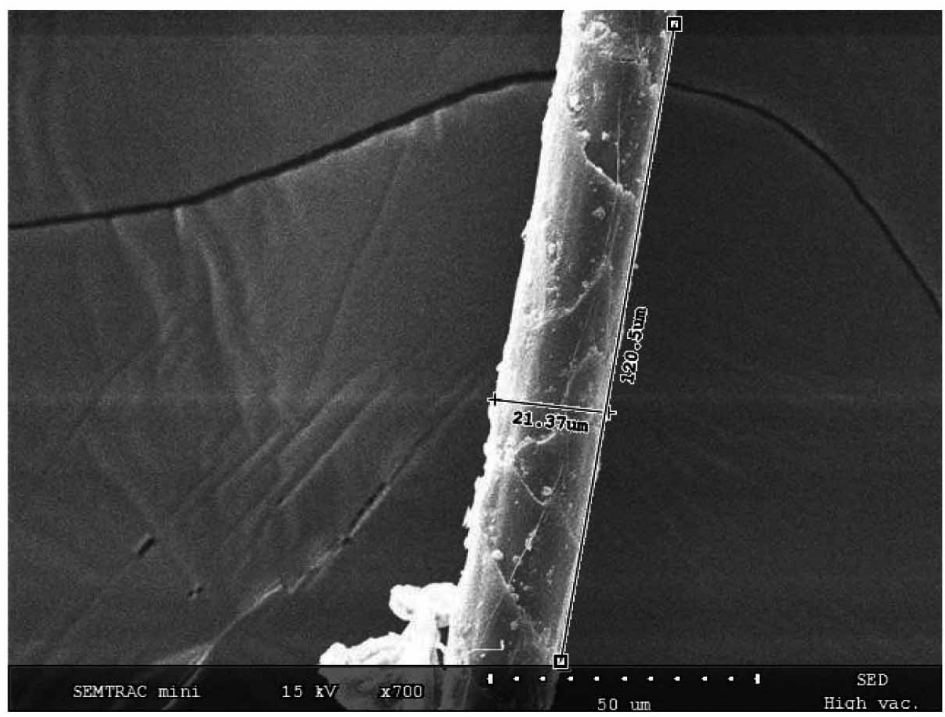

2-p зураг. Ноосны ноолууран ширхэгтийн хайрслаг давхарга (700 дахин өсгөлттэй)

Ноосны үсний ширхэгтүүдийн хайрслаг давхаргын харьцуулсан дүн

\begin{tabular}{|c|c|c|c|c|c|c|c|}
\hline \multirow{2}{*}{$\begin{array}{l}\text { Үсний } \\
\text { төрөл }\end{array}$} & \multirow{2}{*}{ 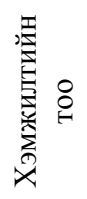 } & \multirow{2}{*}{$\begin{array}{l}\text { Дундаж } \\
\text { голч, мкм }\end{array}$} & \multirow{2}{*}{$\begin{array}{c}1 \text { мм уртад } \\
\text { оногдох } \\
\text { хайрсны тоо, } \\
\text { дундаж }\end{array}$} & \multicolumn{3}{|c|}{$\begin{array}{c}\text { Хайрсны өндөр, } \\
\text { Дундаж, мкм }\end{array}$} & \multirow{2}{*}{ Хайрсны хэлбэр } \\
\hline & & & & их & дундаж & Бага & \\
\hline Ямаан үс & 100 & 124,7 & 67 & 24,4 & 15,03 & 9,12 & $\begin{array}{l}\text { Цагираг биш, олон } \\
\text { өнцөгт хэлбэртэй }\end{array}$ \\
\hline Ноолуур & 100 & 21,37 & 58 & & 15,12 & & Цагираг хэлбэртэй \\
\hline
\end{tabular}


Хөндлөн огтлолын зүсэлтээс харахад ноолуур үсний хөдлөн огтлол (3-p зураг) нь дугариг хэлбэртэй, цайварлаг давхарга нь орто, пара кортексоос тогтдог болох нь батлагдав. Завсрын үсний хөндлөн огтлол (4p зураг) нь зууван хэлбэр рүү шилжсэн, цайварлаг давхарга, хайрслаг давхарга, бага зэрэг хөндий голоос тогтсон байна. Сор үсний хөндлөн огтлол (5-р зураг) нь зууван хэлбэртэй, хөндлөн огтлолын ихэнхи хувийг хөндий гол эзэлсэн, бага зэргийн цайварлаг давхарга, хайрслаг давхаргаас тогтсон байна. Ямаан үсний хөндлөн огтлол (6-р зураг) нь зууван хэлбэртэй, хайрслаг давхарга, хөндлөн огтлолын дийлэнхи хувийг хөндий гол эзэлсэн байна.

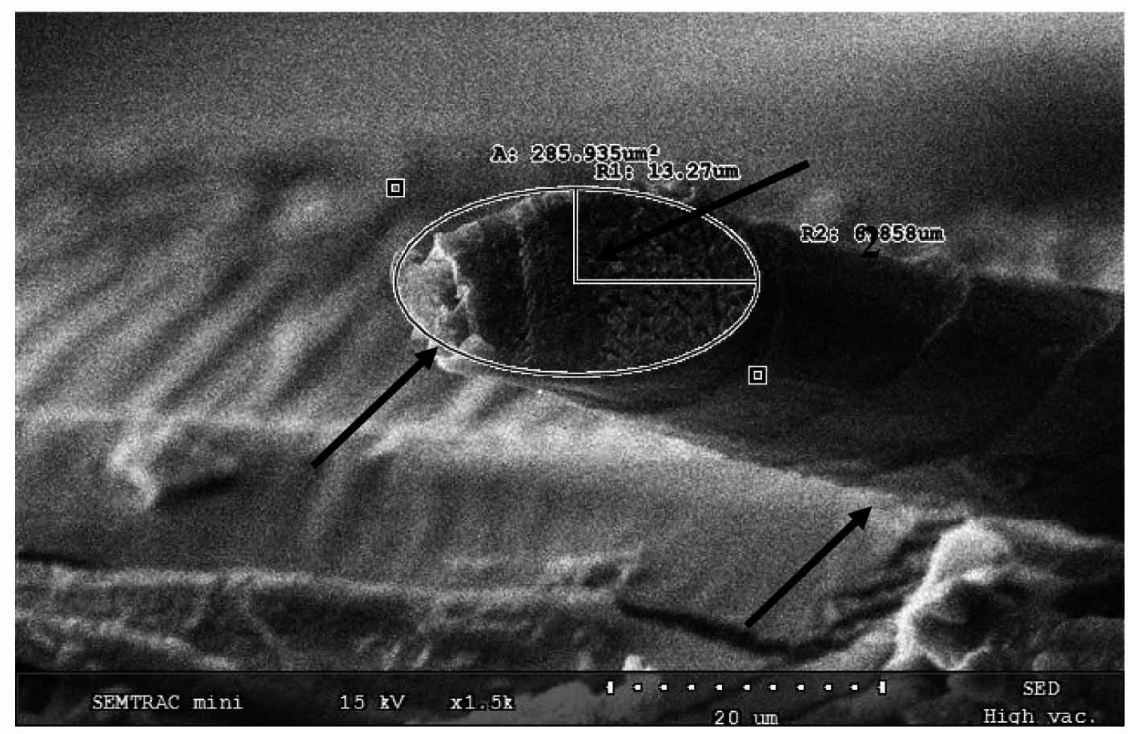

3-р зураг. Ноолууран ширхэгтийн цайварлаг давхарга (1500 дахин өсгөлттэй) Тайлбар: 1-паракортекс, 2-ортокортекс, 3-хайрслаг давхарга

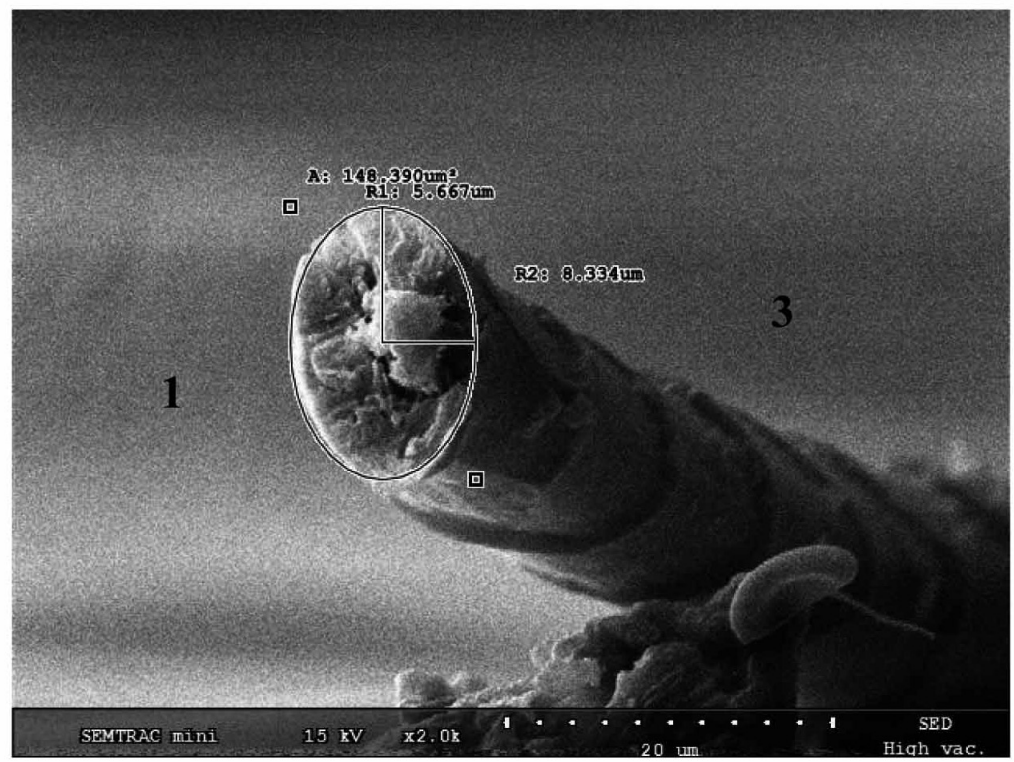

4-р зураг. Завсарын үсний цайварлаг давхарга (2000 дахин өсгөлттэй) 


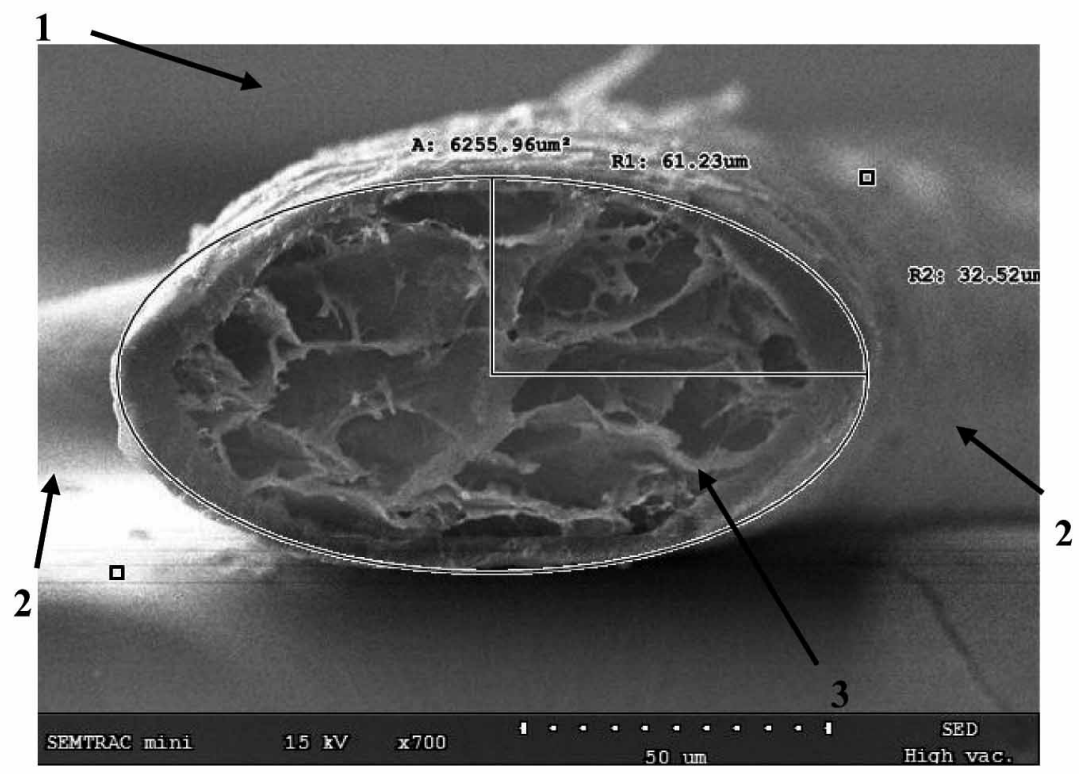

5-р зураг. Сор үсний цайварлаг давхарга (700 дахин өсгөлттэй) Тайлбар: 1-хайрслаг давхарга, 2-цайварлаг давхарга, 3-хөндий гол

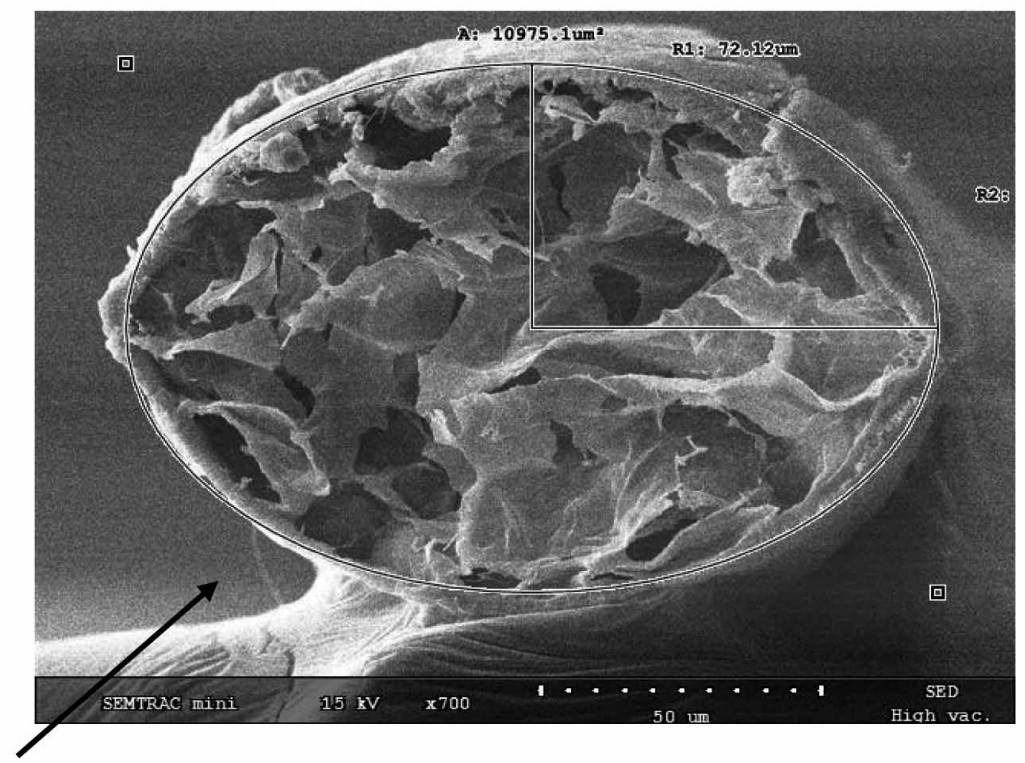

6-р зураг. Ямаан үсний цайварлаг давхарга (700 дахин өсгөлттэй) Тайлбар: 1-хөндий гол

\section{2.Техникийн шинж чанарын судалгаа (голч)}

Хонины ноосны ноолуур үс, завсрын үс, сор үс, ямаан үсний голчийг электрон микроскопоор тодорхойлон математик статистикийн боловсруулалтыг хийлээ (2-p хүснэгт). Судалгааны дүнгээс үзэхэд ноолуур үсний дундаж голч нь 21,37мкм, хазайлт нь $\pm 3,8$; жигд бусын итгэлцүүр 20,8\%, завсрын үсний голч нь 39,6мкм, хазайлт нь $\pm 8,5$; жигд бусын итгэлцүүр $30,1 \%$, сор үсний дундаж голч нь 67,9мкм, хазайлт нь $\pm 12,7$; жигд бусын итгэлцүүр $34,1 \%$, ямаан үсний дундаж голч нь 124,7 мкм, хазайлт нь $\pm 15,0$; жигд бусын итгэлцүүр 46,3\% тус тус байна. Эндээс үзэхэд ноолуур үс нь хамгийн нарийн, ямаан үс нь хамгийн бүдүүн ширхэгт болох нь харагдаж байна. 
Техникийн шинж чанарын зарим үзүүлэлт (голч) үсний төрлөөс хамаарах нь

\begin{tabular}{cccc}
\hline Үсний төрөл & Дундаж утга & Хазайлт, $\sigma$ & $\begin{array}{c}\text { Жигд бусын } \\
\text { итгэлцүүр, CV,\% }\end{array}$ \\
\hline Ноолуур & 21,37 & $\pm 3,8$ & 20,8 \\
Завсрын үс & 39,6 & $\pm 8,5$ & 30,1 \\
Сор үс & 67,9 & $\pm 12,7$ & 34,1 \\
Ямаан үс & 124,7 & $\pm 15,0$ & 46,3 \\
\hline
\end{tabular}

Эдгээр үснүүдийн голчийн тархалтыг гистограммын аргаар тодорхойлон 1-р тахирмагт харуулав.
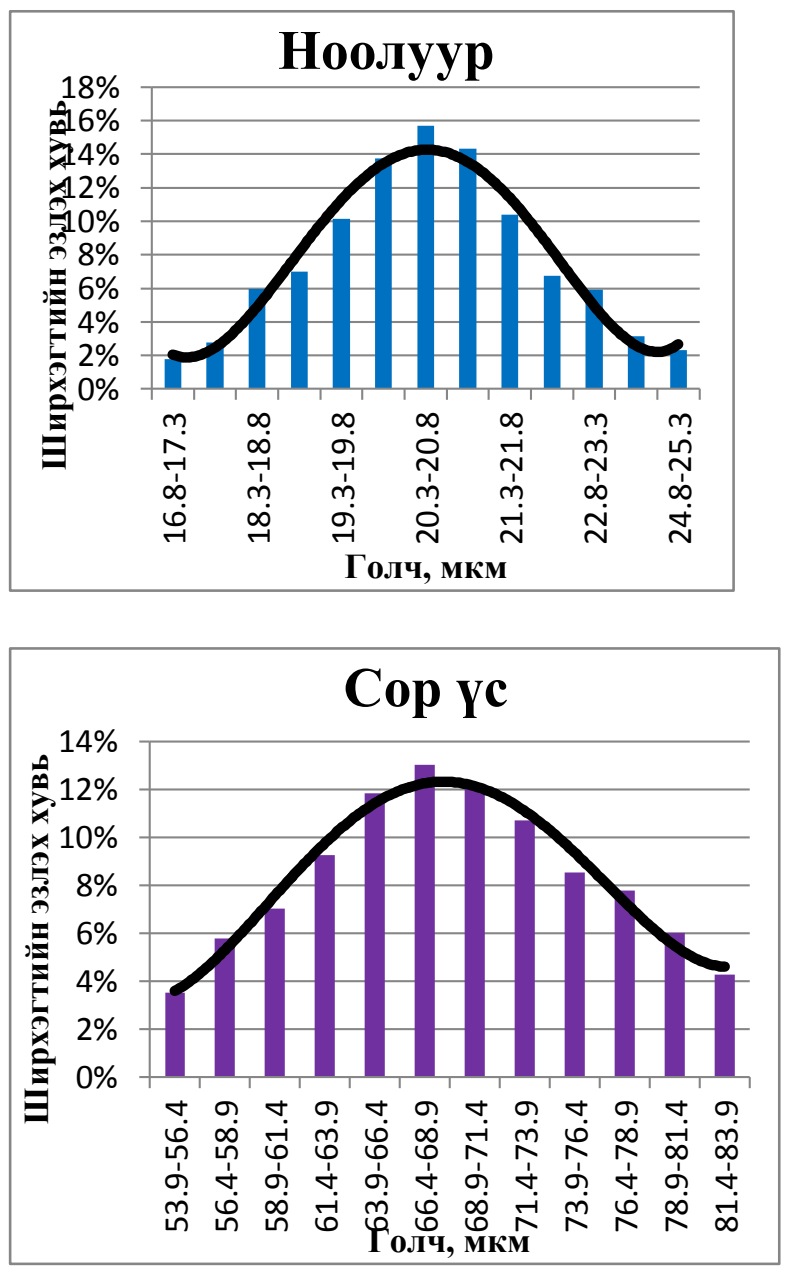

Эдгээр тахирмагаас харахад ноолуур үс, завсарын үс, сор үс, ямаан үсний голчийн тархалт жигд байна.
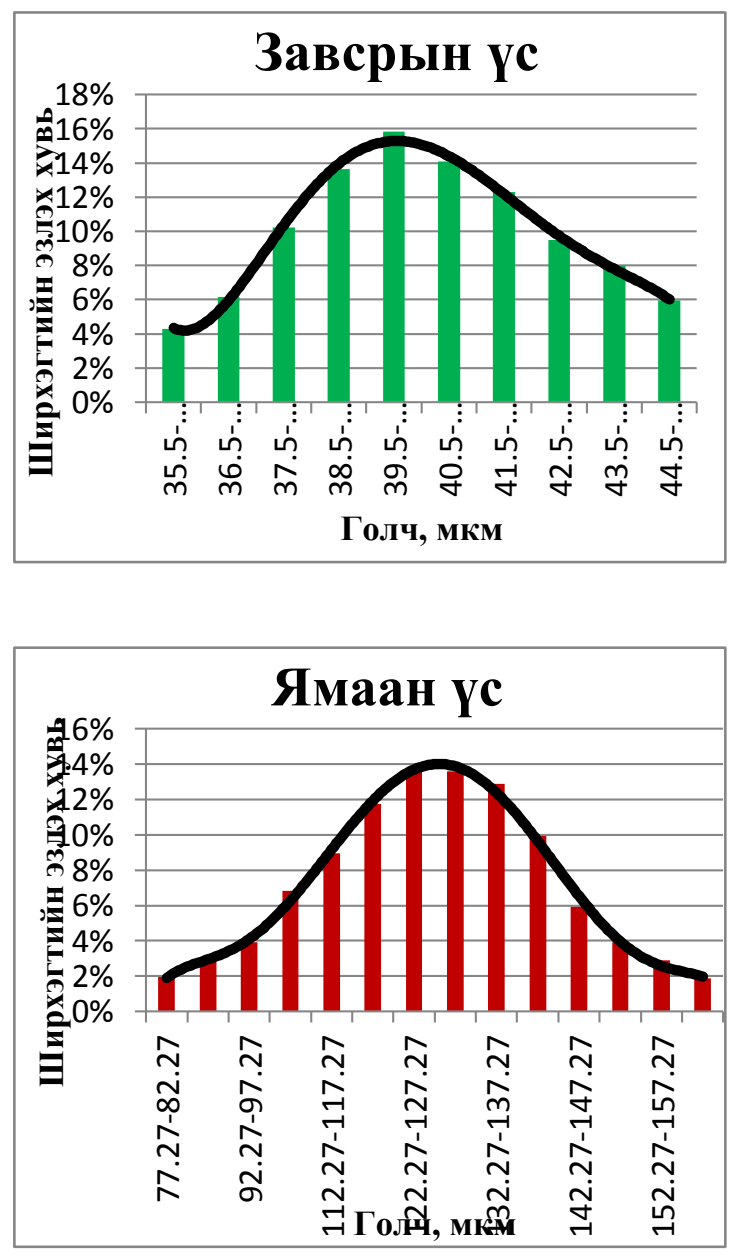

7-р зураг. Ноосон дахь үсний ширхэгтүүдийн голчийн тархалт

\section{3. Харьиуулсан судалгаа}

Хонины ноосны ноолуур, ямаан үсний бүтэц шинж чанарыг харьцуулж үзэхэд

(3-p хүснэг) ноолуур үс нь нарийн, урт, хөнгөн, уян, атираатай, барьцамтгай, ээрэгдэх чадвартай, хөндий голгүй, хайрслаг давхарга, орто пара кортексоос тогтсон цайварлаг давхаргаaс тотсон байхад ямаан үс нь бүдүүн, богино, хүнд, хөшүүн, атираагүй, барьцамтгай биш, ээрэгдэх чадвараар сул, цайварлаг давхаргагүй, хайрслаг давхарга, ширхэгтийн хөндлөн огтлолын дийлэнхи хувийг хөндий гол эзэлсэн байна. Үүнээс улбаалаад ямаан үс нь бүдүүн, хугарамтгай шинж чанартай болдог байна. 
Монгол хонины ноосны ноолуур, хялгасны шинж чанарын үзүүлэлтүүд ялгаа

\begin{tabular}{lcc}
\hline \multicolumn{1}{c}{ Үзүүлэлт } & Ноолууран ширхэгт & Хялгасан ширхэгт \\
\hline Голч & Нарийн & Бүдүүн \\
Урт & Урт & Богино \\
Жин & Хөнгөн & Хүнд \\
Уян чанар & Уян & Хөшүүн \\
Атираа & Атираатай & Атираагүй \\
Барьцамтгай чанар (эсгийрэх) & Барьцамтгай & Барьцамтгай биш \\
Ээрэгдэх чанар & сайтай & сул \\
Хайрслаг давхарга & + & + \\
Цайварлаг давхарга & Орто, пара кортекс & - \\
Хөндий гол & - & Хөндлөн огтлолын дийлэнхи \\
\end{tabular}

\section{ШУУН ХЭЛЭЛЦЭХУЙ}

Хонины ноосны ноолууран ширхэгтийг Ямааны ноолуурын ноолууран ширхэгттэй харьцуулан хүснэгтээр үзүүлэв.

Хонины болон ямааны ноосны ноолууран ширхэгт

\begin{tabular}{lcc}
\hline \multicolumn{1}{c}{ Үзүүлэлт } & $\begin{array}{c}\text { Ноосны Ноолууран } \\
\text { ширхэгт }\end{array}$ & $\begin{array}{c}\text { Ямааны Ноолууран } \\
\text { ширхэгт (Б.Энхтуяа) }\end{array}$ \\
\hline Голч & Нарийн & Нарийн \\
Урт & Урт & Богино \\
Жин & Хөнгөн & Хөнгн \\
Уян чанар & Уян \\
Атираа & Атираатай \\
Барьцамтгай чанар (эсгийрэх) & Барьцамтгай & Атираатай \\
Ээрэгдэх чанар & Сайтай & Барьцамтгай \\
\hline
\end{tabular}

\section{ДУГНЭЛТ}

1. Хонины ноосны хайрслаг давхаргын гистологи бүтцийн судалгаанаас үзэхэд ноолууран ширхэгт нь бие биеэндээ углагдаж байрласан зөв хэлбэрийн хайрснаас тогтдог болох нь тогтоогдсон. Энэ нь уг ширхэгтийг эсгийрэх чадвартай болохыг харуулж байна.

2. Ширхэгтийн хөндлөн огтлолоос үзэхэд ноолууран ширхэгт нь орто, паракортексээс тогтдог болох нь тогтоогдлоо. Энэ нь уг ширхэгт нь атираатай, ээрэгдэх чадвартай байна.

3. Ямаан үс нь хөндий голоос тогтсон болох нь тогтоогдлоо. Ийм учраас уг ширхэгт нь атираагүй ээрэгдэх чадваргүй байна.
4. Ноосны бие биенээсээ ялгаатай ширхэгтүүдийн бүтэц шинж чанарыг судлан тогтоосноор тус бүрээр нь үнэт бүтээгдэхүн үйлдвэрлэх технологийн горим боловсруулах боломжтой юм.

5. Ноосны ноолууран ширхэгт нь ямааны ноолууран ширхэгттэй ойролцоо бүтэц, шинж чанартай болох нь тогтоогдсон. Ийм учраас хонины ноосны ноолуураар өртөг шингэсэн шинэ төрлийн бүтээгдэхүн үйлдвэрлэх боломжтой байна. 


\section{АШИГЛАСАН ХЭВЛЭЛ}

1. Надмид.Г, “Ноос ноолуурын хими-технологийн онол практикийн асуудал” 2009

2. Самбуу.Г, “Хонины аж ахуй”, 2012
3. Хишигжаргал.Ц, “Сарлагийн хөөврийн бүтэц, чанарын онцлогт суурилсан технологийн шийдэл боловсруулах" диссертаци, 2012

4. Чойжил.Д, “Монгол хонины ноосны чанар”, 1967

5. Энхтуяа.Д, ”Монгол ноолуур” 2012 